\title{
Influence of grilling pretreatment and optimization of sous vide processing parameters on the physicochemical and microbiological quality of pirarucu fillet
}

\author{
Enrique Pino-Hernández ${ }^{1,2,3} \oplus$, Wanessa Almeida da Costa ${ }^{4}$, \\ Eder A Furtado Araujo ${ }^{1}$, Pedro M Villa ${ }^{5}$, \\ Lúcia de F Henriques Lourenço ${ }^{1}$ and Raul de Carvalho Junior ${ }^{4}$
}

\begin{abstract}
The demand for high-quality food products has promoted the study of techniques for its processing and conservation. The present research aimed to evaluate the influence of grilling pretreatment on the physical characteristics of pirarucu fillets and the heat transfer process by a computational modelling, and to optimize the sous vide process parameters. Before and after the sous vide process, the samples were analysed for microbiological, chemical and physical characteristics. There was no significant difference between the total experimental time of grilling and that obtained by computational modelling. Immersion in brine for $300 \mathrm{~s}$ in combination with grilling at $200^{\circ} \mathrm{C} / 120 \mathrm{~s}$ was selected because of its water-holding capacity (\%) $79.40 \pm 0.31$, texture (N) $1.91 \pm 0.40$ and value of $L^{*} 74.44 \pm 0.38$ in the fillets. Cooking at $60^{\circ} \mathrm{C}$ for $568.8 \mathrm{~s}$ were the best sous vide parameters obtained, with highest water-holding capacity (\%) 93.60 , texture (N) $6.24, \Delta E^{\star} 7.43$, and with microbiological loads below $6 \mathrm{log} \mathrm{CFU} / \mathrm{g}$ and $7 \mathrm{log} \mathrm{MPN} / \mathrm{g}$ in the final product. Useful information obtained from this study highlighted the brine and grill pretreatment in combination with sous vide proved it is a potential solution for developing pirarucu products even at an industrial scale.
\end{abstract}

\section{Keywords}

Brine, thermal process, grill, Arapaima gigas, vacuum-packaged, sous vide, response surface methodology

Date received: 19 August 2019; accepted: 25 May 2020

\section{INTRODUCTION}

The pirarucu (Arapaima gigas) is the largest freshwater fish in the world that reaches up $2-3 \mathrm{~m}$ and $200 \mathrm{~kg}$. This fish inhabits the Amazon River Basin in South America and it is considered as one of the most important commercial fish species in this region, which has also been well reproduced in captivity (Cortegano et al., 2017). The pirarucu is traditionally preserved and consumed in natura or dry-salted without a good standardized processing method that guarantees its quality and

Food Science and Technology International 27(1) 84-96

(C) The Author(s) 2020 Article reuse guidelines:

sagepub.com/journals-permissions

DOI: $10.1177 / 1082013220934257$

journals.sagepub.com/home/fst

๑SAGE preservation (Pino-Hernández et al., 2020). For this reason, it is essential to assess other processing methods that increase the feasibility of introducing the fish into niche markets as a value-added processed product.

\footnotetext{
${ }^{1}$ LAPOA/FEA (Faculty of Food Engineering), Federal University of Para, Guamá, Belém, Pará, Brazil

${ }^{2} \mathrm{CEB} /$ Center of Biological Engineering, University of Minho, Braga, Portugal

${ }^{3}$ INYCIA Research Group, Sefitrones, Cartagena, Bolivar, Colombia

${ }^{4}$ LABEX/FEA (Faculty of Food Engineering), Federal University of Para, Guamá, Belém, Pará, Brazil

${ }^{5}$ Foundation for the Conservation of Biodiversity, Estado Amazonas, Venezuela

Corresponding author:

Enrique Pino-Hernández, University of Minho, Gualtar Campus, Braga 4710-057, Portugal.

Email: eph@ceb.uminho.pt
} 
Sous vide cooking technology includes a combination of vacuum packaging, cold shock (after thermal processing), and storage of the products at temperatures below $4{ }^{\circ} \mathrm{C}$ for a few hours or days (Baldwin, 2012; Llave et al., 2018). This technology should not be viewed as substitutes for traditional technologies (e.g. brine and grilling), but should be a benchmark for enhancing existing processes and products while improving final product quality (Baldwin, 2012; Kilibarda et al., 2018; Pino-Hernández et al., 2020).

Several authors indicated the viability of using sous vide combined with other food processing techniques for different species of fish, leading to excellent results, such as lemon juice (Cosansu et al., 2013), high pressure (Espinosa et al., 2015) and modified atmosphere packing (Hernández et al., 2017). However, it is still necessary to combine the existing techniques to substantially reduce the damage to the physicochemical characteristics in fish products (Llave et al., 2018).

In this context, sous vide cooking can be applied in combination with previous brine and grilling pretreatment, but then it is essential to establish heat treatment conditions by evaluating the appropriate heat levels for the thermal process, as well as its effect on texture, water-holding capacity (WHC) and fish fillet colour (Baldwin, 2012; Konno, 2017; Llave et al., 2018).

An adequate heating provides fish fillet with acceptable texture through protein denaturation causing shrinkage of muscle fibres and a more compact tissue texture (Yu et al., 2014). On the contrary, an excessive heating spoils colour, texture and other physicochemical attributes, thus the appropriate degree of heating for the grilling process should be determined (Matsuda et al., 2013; Nakamura et al., 2011; Yu et al., 2014). The influences of the heat transfer and heating type on the fish surface determine colour changes during grilling (Matsuda et al., 2013). Grill pretreatment conditions of 175 to $230^{\circ} \mathrm{C}$ are suggested for different types of fish products, allowing the browning to form on the food surface and leading to tastier products that require less cooking time (Llave et al., 2014; Yu et al., 2014).

The effectiveness of the cooking thermal process varies according to the temperature reached and maintained at each point in the food matrix over time, which must be sufficient to inactivate microorganisms and preserve the product (Baldwin, 2012). Therefore, sous vide cooking should receive more attention on potential hazards related to Clostridium, Staphylococcus and Salmonella spp, in order to maintain the microbiological safety (Hernández et al., 2017; Kilibarda et al., 2018).

To our knowledge, there are no data on the characterization of physicochemical changes of pirarucu heattreated by the sous vide process in combination with previous brine and grilling pretreatment. Therefore, the aims of this study were: (1) to characterize the raw material based on the chemical and microbiological characteristics; (2) to evaluate the influence of grilling pretreatment on the physical characteristics of pirarucu fillets; (3) to characterize by computational modelling the heat transfer during the grilling pretreatment based on the temperature profiles and temperature distributions in the samples; (4) to optimize the sous vide process parameters using response surface methodology and desirability function and (5) to control the sous vide cooking in terms of temperature histories and microbiological quality in the final product.

\section{MATERIALS AND METHODS}

\section{Raw material}

The pirarucu samples used in this study were obtained from the industrial production of a fish farming system located in São João de Pirabas, Brazil, where the fish grew in tanks. In this fish farming, the fish were placed in a tank and fasted for $24 \mathrm{~h}$ before slaughter, followed by immersion in cold water at $1 \pm 1{ }^{\circ} \mathrm{C}$ for $1200 \mathrm{~s}$ until death. In this work, the fish in life were not manipulated for the authors.

The raw material was stored with ice in an isothermic container and transported to the Fish Products Laboratory of the Federal University of Para (Belem, Brazil). Once the fish were washed and sanitized ( $5 \mathrm{ppm}$ $\mathrm{NaCl}$ solution for $900 \mathrm{~s}$ ), the dorsal portion was cut, filleted $(15 \mathrm{~cm} \times 8 \mathrm{~cm} \times 2.5 \mathrm{~cm}$, length $\times$ width $\times$ thickness, and weighing approximately $150 \mathrm{~g}$ ), vacuumpacked and stored at $-22{ }^{\circ} \mathrm{C}$ until use.

The total weight of the dorsal portion of pirarucu used for this study was $20 \mathrm{~kg}$. A raw material sample of $1 \mathrm{~kg}$ was used for the microbiological characterization, thermal conductivity and chemical properties analyses. All experiments were conducted in triplicate.

\section{Microbiological analyses}

Microbiological analyses were performed on the raw material and sous vide-treated products. The most probable number technique was used to determine the level of coliforms at $45^{\circ} \mathrm{C}$ and $35^{\circ} \mathrm{C}$, after incubation for $24-48 \mathrm{~h}$. An indicative analysis was performed for coagulase-positive Staphylococcus and Salmonella spp (Downes and Ito, 2015). In addition, counts of total aerobic mesophilic and psychrotrophic bacteria were determined by the pour-plate method, using plate count agar (Oxoid Ltd., London, UK) and incubating at $35^{\circ} \mathrm{C}$ for $48 \mathrm{~h}$ and at $7{ }^{\circ} \mathrm{C}$ for 10 days, respectively. The determination of sulphite-reducing Clostridium uses as a base medium tryptose sulphite cycloserine agar. Plates were placed in an anaerobic jar and incubated at $36 \pm 1{ }^{\circ} \mathrm{C}$ for $24 \mathrm{~h}$. All analyses followed the methodology described by Downes and Ito (2015). 


\section{Thermal and chemical properties analyses}

The thermal conductivity $\left(\mathrm{W} / \mathrm{m}^{\circ} \mathrm{C}\right)$ of the raw material sample was analysed using a KD2 thermal property analyser (Decagon Devices, Inc., Pullman, WA, USA).

The thiobarbituric acid-reactive substances (TBARS) were determined using the methodology proposed by Vieira et al. (2018). The absorbance of the samples was measured at $532 \mathrm{~nm}$. TBARS values were expressed as milligram of malondialdehyde (MDA)eq/ $\mathrm{kg}$ of sample. The $\mathrm{pH}$ value was measured using a digital pH meter (WTW pH 330i Taschen-pH-Meter, WTW GmbH, France). The total volatile bases nitrogen (TVB-N) were analysed according to Cosansu et al. (2013), and the results were expressed as $\mathrm{mg} \mathrm{N} / 100 \mathrm{~g}$ of sample.

\section{Pretreatments of the pirarucu fillet}

As an alternative to improving the technological weaknesses of the conventional sous vide process, a pretreatment on fish fillet was evaluated in two steps.

Immersion in a brine solution. Chemical pretreatment was performed on the raw material sample (around $150 \mathrm{~g}$ of fillet) by immersion in a brine solution (1:1.5 fish (w):brine (v)) at refrigerating temperature for $300 \mathrm{~s}$, then were removed and left to drain for $2 \mathrm{~min}$. The conditions were defined based on the result of a preliminary experiment (data not shown). The brine solution was prepared as a $3 \%(\mathrm{w} / \mathrm{v}) \mathrm{NaCl}$, and the $\mathrm{pH}$ was adjusted with $30 \%$ acetic acid to $\mathrm{pH}$ 2. The fillets were then grilled as described in Sealing on the grill section.

Sealing on the grill. Thermal pretreatment was performed on a stainless-steel grill (PR-650 L, Progas, Brazil) at $100,130,170$ and $200^{\circ} \mathrm{C}$. A skewer-type digital thermometer (Incoterm, Brazil) was placed in the centre of the fillet. The time required for the centre of the fillet to reach a stable temperature of $80^{\circ} \mathrm{C}$ was considered as the heating time, recorded using a PRO-1 timer (Nautika, Brazil). This procedure was performed on both sides of the fillet. The physical analyses such as texture, WHC and colour were determined for each thermal pretreatment.

Complementarily, simulations of heat transfer were conducted for all the temperatures defined for different grilling pretreatments. During the simulations, measurements were taken every $3 \mathrm{~s}$, considering the variation $\Delta x=\Delta y=\Delta z=0.005 \mathrm{~cm}$. This process was followed until the centre of the fillet $(15 \times 8 \times 2.5 \mathrm{~cm}$, length $\times$ width $\times$ thickness) reached a stable temperature of $80^{\circ} \mathrm{C}$. The computational model was developed in MATLAB R2019a” (MATLAB, 2019).
In the heat transfer analysis, the threedimensional (3D) transient heat conduction of a partial differential equation based on Fourier's law was used equation (1)

$$
\frac{\partial T}{\partial t}=\alpha\left(\frac{\partial^{2} T}{\partial x^{2}}+\frac{\partial^{2} T}{\partial y^{2}}+\frac{\partial^{2} T}{\partial z^{2}}\right)
$$

where $T$ is temperature $\left({ }^{\circ} \mathrm{C}\right) ; t$ is time (s); $\alpha$ is thermal diffusivity; $x, y$ and $z$ are the Cartesian coordinates.

The finite difference method (3D) of Geankoplis (1998) was adopted to solve equation (2). Here, the thermal properties of fish are constant in all dimensions. The thermal diffusivity $(\alpha)$ is given by equation (2)

$$
\alpha=\frac{K}{\rho C p}
$$

where $K$ is the thermal conductivity $\left(1.07 \mathrm{~W} / \mathrm{m}{ }^{\circ} \mathrm{C}\right.$, established in this study); $\rho$ is the density $\left(1067 \mathrm{~kg} / \mathrm{m}^{3}\right.$, established previously by Baldwin (2012)); $C_{p}$ is the specific heat capacity $\left(3598 \mathrm{~J} / \mathrm{kg}^{\circ} \mathrm{C}\right.$, established previously by Orrego (2003)).

On the other hand, to visualize the colour changes in the fillet samples before and after thermal processing, digital images were captured on a digital camera (SX40 HS, Canon, Japan) at the resolution of $1920 \times 1080$ pixels (simulating the most likely method used in an industrial setting). The images were acquired freehand in a $90^{\circ}$ angle perpendicular $(60 \mathrm{~cm})$ to the plane where the fillets were located. The lighting system used was standardized; the lamps were positioned in a $45^{\circ}$ angle above the fillet. Images were acquired in the JPEG format, additionally, the brightness was evaluated $\left(L^{*}\right)$ using CorelDRAW software (X6-16, Creative Suite, Cowpland Research Labs, Canada) in order to create a colour scale for this parameter.

\section{Physical analyses}

Texture analyses (shear strength, SS) were performed on the fillet and cooked samples $(2.0 \times 5.0 \times 5.0 \mathrm{~cm}$, thickness $\times$ width $\times$ length), using a QTS-25 texture analyser (Brookfield CNS, United Kingdom) equipped with a Warner-Bratzler blade (thickness of $3.0 \mathrm{~mm}$ and width of $70 \mathrm{~mm}$ ), which was applied to the muscle perpendicularly to the muscle fibres. Test conditions were room temperature, load cell of $5 \mathrm{~kg}$, shear strength (in N) and testing speed of $2.0 \mathrm{~mm} / \mathrm{s}$. The tests were conducted in six fillets for each treatment.

The WHC of the fillet was determined according to Kato et al. (2016) placing the fillet and cooked samples 
between two plates over which a 5-kg weight rested for 5 min. The WHC was calculated using equation (3)

$$
W H C(\%)=\frac{m f}{m i} \times 100
$$

where $m i=$ initial mass $(\mathrm{g})$ of the sample; $m f=$ final mass $(\mathrm{g})$ of the sample.

The Commission Internationale de L'Eclairage (CIE) instrumental colour parameters $\left(L^{*}, a^{*}, b^{*}\right)$ were recorded using a portable chromameter (Minolta, CR-310, Japan) with a D65 light source. In the CIE $L^{*} a^{*} b^{*}$ colour space, $L^{*}$ is brightness (varying from $0=$ black to $100=$ white $), a^{*}$ varies from green $(-$ $\left.a^{*}\right)$ red $\left(+a^{*}\right)$, and $b^{*}$ varies from blue $\left(-b^{*}\right)$ to yellow $\left(+b^{*}\right)$. Total colour difference/variation $\left(\Delta E^{*}\right)$ was calculated using equation (4). The tests were conducted in six fillets for each treatment.

$$
\Delta E^{*}=\sqrt{\left(\Delta L^{*}\right)^{2}+\left(\Delta a^{*}\right)^{2}+\left(\Delta b^{*}\right)^{2}}
$$

where $\Delta L^{*}, \Delta a^{*}$ and $\Delta b^{*}$ are the differences between the colour parameter of the samples processed and the colour parameter of the control sample (unprocessed fillet) $L^{*}=63.36 \pm 1.65, \quad a^{*}=-4.07 \pm 0.22$ and $b^{*}=7.67 \pm 0.58$.

\section{Preparation of pirarucu sous vide product}

The raw sample weighing approximately $150 \mathrm{~g}$ and with dimensions of $15 \mathrm{~cm} \times 8 \mathrm{~cm} \times 2.5 \mathrm{~cm}$, length $\times$ width $\times$ thickness, was first pretreated chemically and thermally under the conditions that showed the better physical analyses (Physical analyses section). Next, the pirarucu fillet was vacuum-packed (1:4 fish (w):tucupi sauce (v)), using a packaging machine (F200 Flash, Fastvac, Brazil). Once packaged, the product was pasteurized in a water bath (TE-057, Tecnal, Brazil) at atmospheric pressure using the time and temperature set by the response surface methodology. After sous vide processing, the packaged product was cooled in an ice-water solution, with manual stirring until the centre of the fillet reached $0{ }^{\circ} \mathrm{C}$ and then stored under refrigeration $\left(1 \pm 1^{\circ} \mathrm{C}\right)$.

\section{Optimization of the sous vide parameters using response surface methodology}

The parameters of time-temperature of the sous vide process were defined according to a $2^{2}$ full factorial design in a rotational central composite design (CCD), consisting of four linear trials at two levels $(+1$ and -1$)$, with axial points $-\alpha$ and $+\alpha(-1.41$ and +1.41 , respectively), and three trials at the centre point as recommended by Kato et al. (2016). The factors used were time and temperature, and the dependent variables determined were characteristics such as WHC (juiciness, as previously described by Kato et al. (2016)), texture (SS) and $\Delta E^{*}$. High values of WHC, SS and $\Delta E^{*}$ were sought so that the product would maintain its juiciness, texture and colour, according to the initial, full models (equation (5)) the resulting models (response surface models) were found when the WHC, SS and $\Delta E^{*}$ significance levels were $p<0.05$ or near values

$$
\begin{aligned}
Y= & f(X 1,2)=\beta_{0}+\beta_{1}(A)+\beta_{11}(A)^{2} \\
& +\beta_{2}(B)+\beta_{22}(B)^{2}+\beta_{12}(A B)
\end{aligned}
$$

where $Y$ represents the response variable; $X_{i}(i=1,2)$ represents the design variables; $A$ is process time $\left({ }^{\circ} \mathrm{C}\right)$; $B$ is process temperature (s). The coefficients of the polynomial equation were represented by $\beta_{0}$ (constant term); $\beta_{1}$ and $\beta_{2}$ (linear coefficients); $\beta_{11}^{2}$ and $\beta_{22}^{2}$ (quadratic coefficients) and $\beta_{12}$ (interaction coefficients).

Complementarily, the desirability function was applied considering a level of significance of $5 \%$ in order to determine the best operational conditions of time-temperature about the responses WHC, SS and $\Delta E^{*}$ for the sous vide product.

\section{Control of the sous vide process}

Two procedures were conducted to evaluate the sous vide process performed under the best time-temperature identified: (i) thermal profiles - a skewer-type digital thermometer (Incoterm, Brazil) was placed in the centre of the fillet considered as the slowest heating point, with an acquisition interval of $5 \mathrm{~s}$ and data points were then collected in an Excel ${ }^{\circledR}$ worksheet, registering the start and the end of each stage (processing, cooling and reheating) for calculating the pasteurization units and the degree of cooking considering the total thermal process. The reference temperature was set equal to $60^{\circ} \mathrm{C}$ and $z$ at $5.5^{\circ} \mathrm{C}$ (Salmonella spp) for pasteurization units, and equal to $100^{\circ} \mathrm{C}$ and $z$ at $33^{\circ} \mathrm{C}$ for cook value (Rinaldi et al., 2014); and, (ii) microbiological control - before and after the sous vide process the samples were analysed for Salmonella spp, sulphitereducing Clostridium, coagulase-positive Staphylococcus, coliforms at $35^{\circ} \mathrm{C}$ and $45^{\circ} \mathrm{C}$ and counts of total aerobic mesophilic and psychrotrophic bacteria.

\section{Statistical analysis}

To compare means of the physical variables among experimental thermal treatments, it used a one-way analysis of variance (ANOVA) followed by a post 
hoc Tukey's test $(p<0.05)$. The total heating time (i.e. experimental time and time given by threedimensional transient heat conduction of a partial differential equation based on Fourier's law, as previously described by Geankoplis (1998)) and microbiological data (before and after sous vide process) were compared using a Student's $t$-test at a significance level of $5 \%$. Finally, to determine the optimum conditions of time-temperature of the sous vide process, the significant effects $(p<0.05$ or near values) were tested using ANOVA, and also, the response surface to the complete $2^{2}$ factorial design (CCD) as well as the desirability function (obtained from the experimental responses of the physical parameters) were considered. All statistical analyses were undertaken using Statistica software version 5.0 (Statsoft, Inc., Tulsa, OK, USA).

\section{RESULTS AND DISCUSSION}

\section{Microbiological and chemical properties of raw material}

The results of the microbiological analyses of coliforms at $45^{\circ} \mathrm{C}$ of the raw material, Salmonella spp. and coagulase-positive Staphylococcus were $2.52 \log \mathrm{MPN} / \mathrm{g}$, absence in $25 \mathrm{~g}$ and $1 \log \mathrm{CFU} / \mathrm{g}$, respectively. According to Brasil (2001a) and ICMSF (2011), these values are within the recommended limits for fresh fish coliforms at $45^{\circ} \mathrm{C}(2 \log \mathrm{MPN} / \mathrm{g})$, Salmonella spp. (absence) and coagulase-positive Staphylococcus (3 log $\mathrm{MPN} / \mathrm{g}$ ).

The chemical properties data of the raw material were $\mathrm{pH} 5.96 \pm 0.03$, TVB-N of $2.00 \pm 0.03 \mathrm{mg} \mathrm{N} /$ $100 \mathrm{~g}$ and TBARS of $0.40 \pm 0.04 \mathrm{mg}$ MDAeq $/ \mathrm{kg}$. According to several authors, Brasil (2001b), Özyurt et al. (2009), Hernández et al. (2017) and Vieira et al. (2018) these values are within the recommended limits such as $\mathrm{pH} \quad 6.0, \quad$ TVB- $\mathrm{N}<30 \mathrm{mg} \quad \mathrm{N} / 100 \mathrm{~g}$ and TBARS $<3 \mathrm{mg}$ MDA $/ \mathrm{kg}$ for fresh fish.

\section{Effects of brine and different time- temperatures of grilling pretreatment on the physical characteristics of the pirarucu fillet}

The thermal pretreatment results indicated significant differences $(p<0.05)$ in the WHC, texture and colour $\left(L^{*}, a^{*}, b^{*}\right)$ of the pirarucu fillets between treatments (Table 1). The goal of sealing the fillets on a grill was to obtain an 'improved' WHC and texture, and inducing colour variation, and not to cook the product.

In treatment $\mathrm{T} 1$, a mass transfer of water (water loss $\sim 28 \%$ ) from the inner fillet to the heat source was identified, occurring during the first $40 \mathrm{~s}$ of the heating process due to the release of free water present in the fillet which is possibly a consequence of the protein denaturation. Kong et al. (2007) showed that this water loss occurs as a result of the reduced interfibrillar volume, caused by shrinkage of the myofilaments.

Comparatively shorter times were used at higher temperatures, producing an increase in $\mathrm{WHC}$, where treatment $\mathrm{T} 4$ provided the 'best' results with an average cook loss of around $6.80 \%$. Above $170{ }^{\circ} \mathrm{C}$, the cooking loss percentage was decreased. The changes observed on the surface of the fillet, such as less uniformity, were probably induced by the temperature, which causes protein denaturation (Kong et al., 2007). The actomyosin complex is responsible for the fish's ability to retain muscle water, and the high value of WHC observed in this study indicates good muscle quality (Kong et al., 2007).

From the texture analysis significant differences $(p<0.05)$ were found when comparing all treatments. The treatments $\mathrm{T} 1$ and $\mathrm{T} 2$ presented the maximum and minimum values of shear strength, respectively, which

Table 1. Experimental results obtained for different conditions of sealing the pirarucu fillets after grilling pretreatment

\begin{tabular}{|c|c|c|c|c|}
\hline \multirow[b]{3}{*}{ Parameters } & \multicolumn{4}{|l|}{ Treatments } \\
\hline & \multirow{2}{*}{$\frac{T_{1}}{100^{\circ} \mathrm{C} / 330 \mathrm{~s}}$} & \multirow{2}{*}{$\frac{T_{2}}{130 \circ \mathrm{C} / 240 \mathrm{~s}}$} & \multirow{2}{*}{$\frac{T_{3}}{170 \circ \mathrm{C} / 150 \mathrm{~s}}$} & \multirow{2}{*}{$\frac{T_{4}}{200^{\circ} \mathrm{C} / 120 \mathrm{~s}}$} \\
\hline & & & & \\
\hline WHC (\%) & $72.04 b \pm 0.35$ & $74.41 a b \pm 0.42$ & $76.46 \mathrm{ab} \pm 0.23$ & $79.40 c \pm 0.31$ \\
\hline SS (N) & $2.26 a \pm 0.41$ & $1.41 b \pm 0.48$ & $1.93 a b \pm 0.45$ & $1.91 \mathrm{ab} \pm 0.40$ \\
\hline \multicolumn{5}{|l|}{ Colour } \\
\hline$L^{*}$ & $83.57 a \pm 0.23$ & $82.04 a b \pm 0.22$ & $81.58 b \pm 0.34$ & $74.44 c \pm 0.38$ \\
\hline$a^{*}$ & $-4.35 c \pm 0.19$ & $-3.51 b \pm 0.16$ & $-3.94 b c \pm 0.26$ & $-1.55 a \pm 0.19$ \\
\hline$b^{*}$ & $14.58 \mathrm{~b} \pm 0.65$ & $14.88 b \pm 0.31$ & $14.32 b \pm 0.58$ & $22.24 \mathrm{a} \pm 0.27$ \\
\hline
\end{tabular}

WHC: water-holding capacity; SS: texture.

Results are mean \pm standard deviation $(n=3)$. Different letters in the same line indicate statistical significant difference $(p<0.05)$. 
indicate these treatments may affect the tenderness of muscle considering this parameter is correlated with the WHC (Table 1). Changes in the texture of pirarucu fillets during the thermal process were similar to the previously reported by Kong et al. (2007) for salmon (Oncorhynchus gorbuscha).

On the other hand, when compared the colour parameters, the $\mathrm{T} 1$ showed fillets with highest value of lightness $\left(L^{*}\right)$, while T4 resulted in dark-brown fillets associated with lowest value of $L^{*}$, which is an evident browning reaction as Maillard due to the temperature of process in the presence of proteins and carbohydrates. Llave et al. (2014) and Yu et al. (2014) found the outer surface appearance typical of grilled food is achieved when the food is at temperatures ranging between 175 and $200^{\circ} \mathrm{C}$ as obtained in this study.

The colour parameters $a^{*}$ and $b^{*}$ indicated that the fish fillet tended to maintain its redness and yellowness, respectively, and this was attributed to the increased in the pretreatment temperature. Llave et al. (2014) and Matsuda et al. (2013) found that when brightness $\left(L^{*}\right)$ of the sample colour is decreased, the parameters $a^{*}$ and $b^{*}$ increased. This behaviour was also observed in the present study. The results of the thermal pretreatment showed that the colour changes on the surface of the pirarucu fillet caused by this pretreatment could be predicted based on water evaporation, together with the increase of the surface temperature and the processing time. Similar results were found by Nakamura et al. (2011), Matsuda et al. (2013) and Kong et al. (2007) when they studied changes in the colour parameters in fish fillet during grilling under different heat transfer systems. They confirmed that the surface browning colour developed is independent of the heat transfer system.

The synergy between the immersion of pirarucu fillet in the brine solution for $300 \mathrm{~s}$, followed by sealing at $200^{\circ} \mathrm{C}$ on a grill for $120 \mathrm{~s}$ had an important role in preventing discolouration associated with the appearance of white precipitates on the surface of the fillets due to the pretreatment conditions used before the sous vide process, which induced to changes in denaturation of protein and gelation and solubilization of collagen. Konno, (2017) and Llave et al. (2018) identified that the effects of the thermal process and the immersion of the fish fillet in a brine solution allow the denaturation of myosin, and actin is affected by salt concentration and process temperature. This fact may be the reason why the white precipitate on the surface of the fillets was not observed. Therefore, among the treatments evaluated, treatment $\mathrm{T} 4$ was selected because of its highest WHC, tenderness texture (shear strength) and more attractive colour (browning) on the fillet surface.

\section{Digital images and simulation results of the fillet pretreatment}

The colour changes after heating processes were confirmed by comparison with the scale obtained for parameter $L^{*}$ (Figure 1(a)). These results were similar to those described by Llave et al. (2014) when comparing the digital images and $L^{*}$ colour scale in fillets of white muscle fish after heating. The digital images acquired for each thermal pretreatment exhibited visual differences at the end of the process, due to the influences of the temperature and process time, ambient temperature, air flow and the heterogeneity of the fish muscle (Figure 1(b)).

The digital images of the pirarucu fillet surface and images of simulations of the heat transfer effect registered the temperature of $25^{\circ} \mathrm{C}$ in the fillet sample in natura, with a tendency towards bright pink (Figure $1(b)$ and 1(c)). Conversely, when the surface temperature of the fillet reached $100^{\circ} \mathrm{C}$ (Figure 1(b), 1(c) and 1(d)), lightness $\left(L^{*}\right)$ reached its maximum value, possibly due to protein coagulation. Our finding is in agreement with previous observations that protein denaturation causes the fish muscle to become whiter at the beginning of the heating process (Dima et al., 2012).

Subsequently, the treatments at 130,170 and $200^{\circ} \mathrm{C}$ showed a tendency towards moderately darker colours, resulting in the gradual reduction of $L^{*}$. This parameter reached a minimum value for the sample treated at $200{ }^{\circ} \mathrm{C}$ for $120 \mathrm{~s}$, because of the test temperature, which facilitates rapid water evaporation.

The browning reaction occurs by the rapid evaporation of the water during the first minutes, when a high heating process is applied. It may facilitate the increase of temperature and heat transfer by both conduction and convection. In this study, desirable changes in colour on the fillet surface began when the temperature reached approximately $120^{\circ} \mathrm{C}$ (Figure 1(b)). Moreover, at $200^{\circ} \mathrm{C}$ for $240 \mathrm{~s}$, a carbonization reaction is estimated to occur on the surface, resulting in undesirable product characteristics. Thus, most changes in the fillet occur within the first 10 minutes of heating haeme proteins (haemoglobin and myoglobin) denaturation make the fish muscle undergo a rapid whitening phase at the beginning of thermal treatment (up to $95^{\circ} \mathrm{C}$ ) and a slow browning phase at the end (above $150^{\circ} \mathrm{C}$ ) due to the denaturation of protein and the water evaporating gradually (Kong et al., 2007; Nakamura et al., 2011; Yu et al., 2014).

On the other hand, there was no significant difference $(p<0.05)$ when comparing the total experimental time of heating with that obtained by mathematical modelling (Table 2). The mathematical simulations revealed that rapid thermal conduction occurred in the fish samples. It is initially considered that all of 


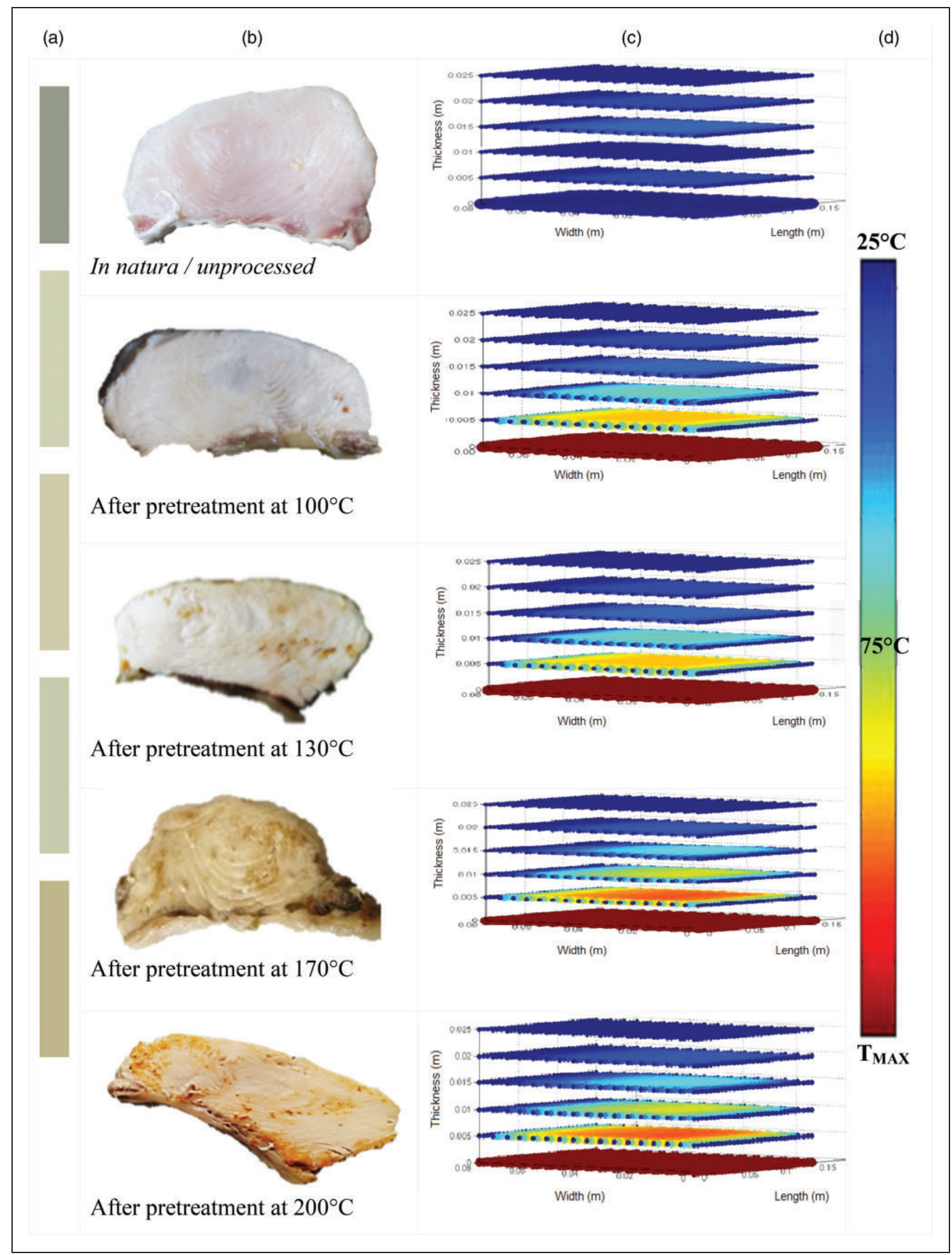

Figure 1. Colour scale for parameter $L^{*}(a)$; digital images of the pirarucu fillet surface (b); simulation results of the heat transfer effect (c) and temperature scale (d).

the internal points of the fish are at $25^{\circ} \mathrm{C}$, while the surface of the fillet in contact with the heating source reaches the temperature of the grill process immediately (Figure 1(c)).
The thermal processes modelling explicitly described the heat transfer, and accompanied by a colour map, simulated the experimental conditions of the processes. (Figure 1(c)). Similar results were found by Llave et al. 
(2014), in which a mathematical approach is used in order to model and predict the expected temperature distribution in fish muscle along the thermal process.

About halfway through each process, the samples were turned, and they showed the same behaviour that appeared in the simulations. This response ensured the formation of a crust on the surface of the fillet when reaching the process temperature, which, in the simulations, is observed by the red colour (Figure 1(c)). As the heating process progressed, the profile colours constantly changed, presenting two main heat flows. The largest temperature gradient was seen on the fillet surface in contact with the hot grill, presenting an upward trend in the centre of the sample, and a little temperature gradient loss in the boundaries of the fillet possibly due to the boundary conditions maintained at lower temperatures (Figure 1(c)).

Table 2. Experimental and modelled times of grill pretreatments for heating to $80^{\circ} \mathrm{C}$ at the centre point of the pirarucu fillets

\begin{tabular}{llll}
\hline & \multicolumn{2}{l}{$\begin{array}{l}\text { Initial and target } \\
\text { temperature of }\end{array}$} & Total heating time $(\mathrm{s})$ \\
\cline { 3 - 4 } $\begin{array}{l}\text { Temperature } \\
\text { of the grill }\left({ }^{\circ} \mathrm{C}\right)\end{array}$ & $\begin{array}{l}\text { the centre point } \\
\text { of the fillets }\left({ }^{\circ} \mathrm{C}\right)\end{array}$ & $\mathrm{t}_{1}$ & $\mathrm{t}_{2}$ \\
\hline 100 & 25 to $>80$ & $382.8 \mathrm{a}$ & $330.0 \mathrm{a}$ \\
130 & & $273.0 \mathrm{a}$ & $240.0 \mathrm{a}$ \\
170 & & $172.2 \mathrm{a}$ & $150.0 \mathrm{a}$ \\
200 & & $168.0 \mathrm{a}$ & $120.0 \mathrm{a}$ \\
\hline
\end{tabular}

${ }_{1}{ }_{1}$ : time given by the Fourier equation; $t_{2}$ : experimental time. Different letters in the same line indicate statistical significant difference $(p<0.05)$.

\section{Optimization of sous vide parameters using response surface methodology and desirability function}

The design matrix (in real and coded forms) and its respective levels are presented along with the experimental values of the WHC, $\Delta E^{*}$ and SS obtained at laboratory scale after the sous vide process, in Table 3. The greatest SS $(7.65 \mathrm{~N})$, the largest $\Delta E^{*}$ preventing the appearance of white protein precipitates on the fillets (9.61), and the maximum WHC (93.59\%) were obtained when the experiments were conducted at 60 , 65 and $75^{\circ} \mathrm{C}$, respectively.

The significant linear, quadratic and interaction effects of the full, initial response surface models are shown in Table 4. It is highlighting that the value of $F$ calculated for the lack-of-fit was significant for the variable WHC, while the same parameter for $\Delta E^{*}$ and SS was not significant (Fcal $<$ Ftab), which suggests that the reduced models (simpler) can be used for predictive purposes in the experimental domain studied (Table 4). In addition, the $R^{2}$ value was $\geq 0.83$ for $\Delta E^{*}$ and SS parameters studied, which suggests that the model appropriately defined the process behaviour by explaining $83 \%$ of the variation in the experimental data. Therefore, it was possible to determine the 'best' condition of the binomial time-temperature of the sous vide process.

The $\Delta E^{*}$ and SS parameters depended directly and linearly on time and temperature, respectively (Table 4). Except for the temperature, other parameters had a negative effect. Time had a marked influence on the WHC in the fillet muscle, such that an increase in this factor resulted in a reduction in the WHC, making

Table 3. Levels of the process variables used in the full factorial design $\left(2^{2}\right)$ composed of central and axial points and experimental results for WHC, $\Delta E^{\star}$ and SS obtained under different sous vide temperature and time conditions

\begin{tabular}{|c|c|c|c|c|c|c|c|}
\hline \multirow[b]{2}{*}{ Assay } & \multicolumn{2}{|c|}{ Coded values } & \multicolumn{2}{|c|}{ Real values } & \multicolumn{3}{|c|}{ Means of experimental results } \\
\hline & Time & Temperature & Time (s) & Temperature $\left({ }^{\circ} \mathrm{C}\right)$ & WHC (\%) & $\Delta E^{\star}(-)$ & SS (N) \\
\hline 01 & -1 & -1 & 600 & 65 & 93.59 & 4.17 & 7.45 \\
\hline 02 & 1 & -1 & 750 & 65 & 92.52 & 5.71 & 7.29 \\
\hline 03 & -1 & 1 & 600 & 85 & 92.44 & 5.81 & 7.40 \\
\hline 04 & 1 & 1 & 750 & 85 & 92.28 & 4.39 & 7.00 \\
\hline 05 & -1.41 & 0 & 568.8 & 75 & 84.33 & 7.68 & 7.41 \\
\hline 06 & 1.41 & 0 & 780.6 & 75 & 85.46 & 9.61 & 7.47 \\
\hline 07 & 0 & -1.41 & 675 & 60 & 89.97 & 7.35 & 7.65 \\
\hline 08 & 0 & 1.41 & 675 & 89 & 92.08 & 6.79 & 6.89 \\
\hline 09 & 0 & 0 & 675 & 75 & 92.19 & 4.61 & 7.50 \\
\hline 10 & 0 & 0 & 675 & 75 & 91.68 & 2.30 & 7.20 \\
\hline 11 & 0 & 0 & 675 & 75 & 92.01 & 2.80 & 7.30 \\
\hline
\end{tabular}

WHC: water-holding capacity; $\Delta E^{\star}$ : colour variation; SS: texture. 
Table 4. Estimated effect and degree of statistical significance for the residual error and pure error for WHC, $\Delta E^{\star}$ and $S S$ related to sous vide process optimization (full response surface models)

\begin{tabular}{|c|c|c|c|c|c|c|c|}
\hline \multirow[b]{2}{*}{ Response } & \multirow[b]{2}{*}{ Factors } & \multirow[b]{2}{*}{ Effect } & \multirow[b]{2}{*}{ Standard error } & \multirow[b]{2}{*}{$P$ value } & \multicolumn{2}{|l|}{$F$ value } & \multirow[b]{2}{*}{$R^{2}$} \\
\hline & & & & & Regression & Lack-of-fit & \\
\hline \multirow[t]{8}{*}{ WHC } & Constant & 91.010 & 1.018 & & 218.26 & 96.405 & 0.80 \\
\hline & Linear (L) & & & & & & \\
\hline & $A$ & -4.593 & 1.201 & 0.001 & & & \\
\hline & $B$ & 1.428 & 1.887 & 0.029 & & & \\
\hline & Quadratic (Q) & & & & & & \\
\hline & $A A$ & -1.158 & 0.747 & 0.007 & & & \\
\hline & $B B$ & -0.191 & 1.779 & 0.499 & & & \\
\hline & Interaction $A B$ & 1.317 & 1.685 & 0.027 & & & \\
\hline \multirow[t]{9}{*}{$\Delta E^{\star}$} & Constant & 3.741 & 0.666 & & 5.39 & $1.217^{\mathrm{ns}}$ & 0.83 \\
\hline & Linear (L) & & & & & & \\
\hline & $A$ & 3.389 & 0.786 & 0.044 & & & \\
\hline & $B$ & -0.761 & 1.235 & 0.580 & & & \\
\hline & Quadratic (Q) & & & & & & \\
\hline & $A A$ & 1.456 & 0.489 & 0.087 & & & \\
\hline & $B B$ & 3.568 & 1.165 & 0.082 & & & \\
\hline & Interaction $A B$ & -0.788 & 1.103 & 0.526 & & & \\
\hline & Model & $3.74+$ & $9(A)$ & & & & \\
\hline \multirow[t]{9}{*}{ SS } & Constant & 7.317 & 0.059 & & 6.53 & $0.279^{\text {ns }}$ & 0.87 \\
\hline & Linear (L) & & & & & & \\
\hline & $A$ & 0.064 & 0.070 & 0.563 & & & \\
\hline & $B$ & -0.548 & 0.110 & 0.064 & & & \\
\hline & Quadratic (Q) & & & & & & \\
\hline & $A A$ & 0.060 & 0.044 & 0.087 & & & \\
\hline & $B B$ & -0.072 & 0.104 & 0.654 & & & \\
\hline & Interaction $A B$ & -0.185 & 0.098 & 0.526 & & & \\
\hline & Model & $7.32-$ & $7(B)$ & & & & \\
\hline
\end{tabular}

$A$ : coefficient of the time of the process $\left({ }^{\circ} \mathrm{C}\right)$; $B$ : coefficient of the temperature of the process (s); WHC: water-holding capacity; $\Delta E^{\star}$ :

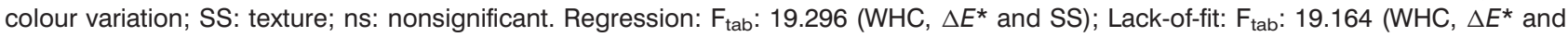
SS).

the product less juicy. The sous vide process improved the WHC, as this is not lost by exudation and evaporation. The water acts as a plasticizer of muscle proteins, and the water is lost from the myofibrillar structure as a result of protein denaturation, with consequent reductions in the volume of muscle fibres as the cooking temperature is increased. The changes in the arrangement of the myofibrillar structure also affect the light-scattering properties and the perceived whiteness of the fish meat (Yu et al., 2014).

The factor with the greatest positive impact on the $\Delta E^{*}$ was time $(A)$, such that an increase in time caused a higher tendency to browning, which is important for the product appearance. Colour variation during thermal processes involves four steps: (i) protein denaturation; (ii) water evaporation; (iii) the browning reaction and (iv) the carbonization reaction (Llave et al., 2014).
In our study, the $L^{*}$ parameter was the best indicator of the colour changes of the fillet surface when compared with $a^{*}$ and $b^{*}$, these colour variations are most apparent with the increasing of temperature.

The temperature $(B)$ negatively affected the muscle SS in pirarucu fillet, which is not a favourable result for product quality. This pattern was also observed in a previous study, wherein a linear decrease in fish muscle texture started at $60^{\circ} \mathrm{C}$ (Kato et al., 2016).

The response surface and its respective contour lines generated by the models proposed for $\Delta E^{*}$ and the SS response are shown in Figure 2(a) and 2(b), respectively. Through the response surfaces and level curves, it was evident that the $\Delta E^{*}$ of the sous vide depended directly and linearly on time, while the SS depended directly on temperature. 


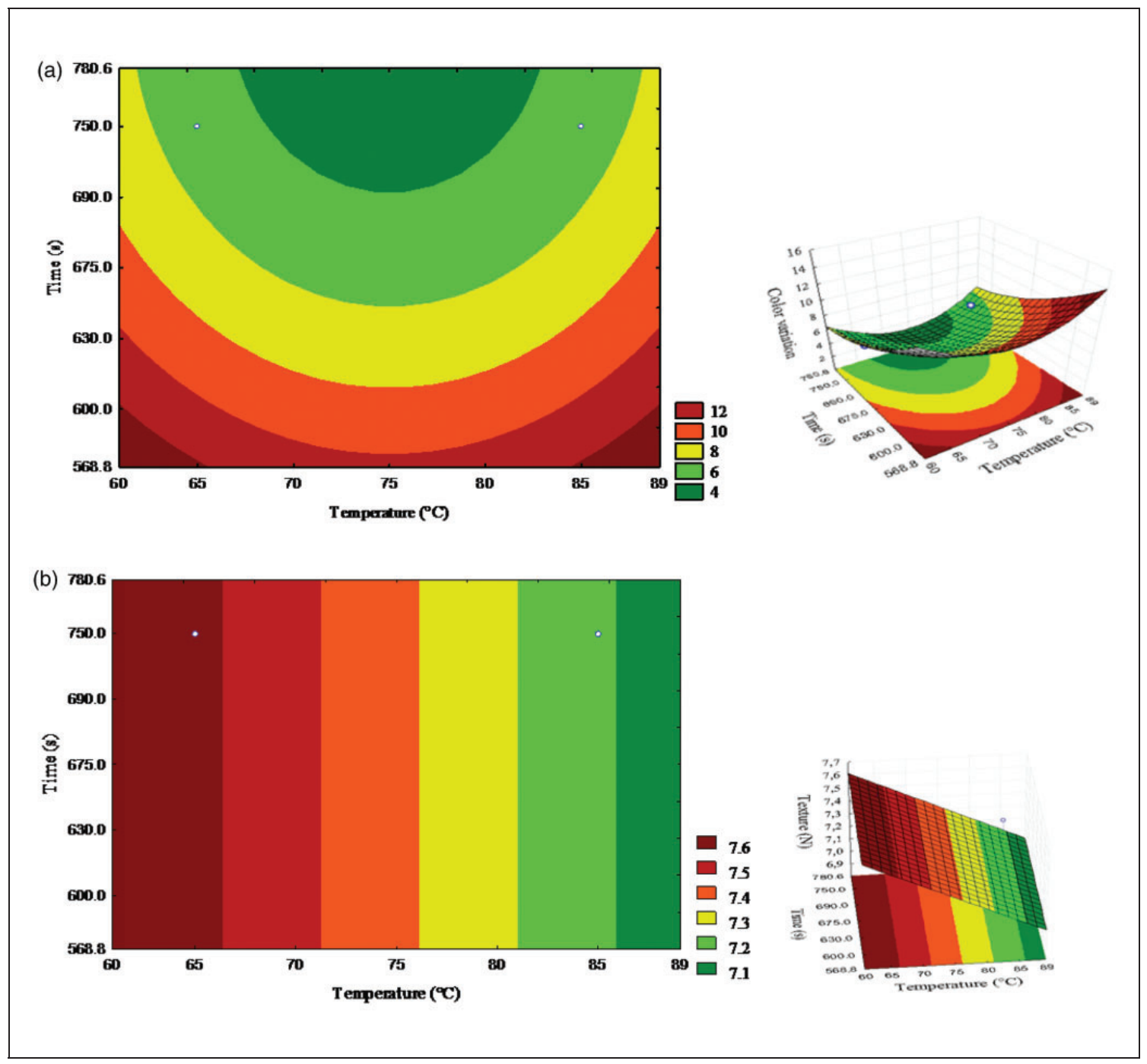

Figure 2. Contour lines and response surface showing the effect of colour variation (a) and texture (b).

The results obtained with the CCD design and through the desirability function showed that it was possible to set the binomial time-temperature conditions of the pirarucu sous vide in the evaluated experimental area (Figure 3). In this figure, the trends revealed by the time-temperature factors are represented by the horizontal blue dashed lines (the top three graphs), which register the average value of each dependent variable. The intersection of the red lines in the corresponding graphs indicates the graph maximum for the variables $\mathrm{WHC}, \mathrm{SS}$ and $\Delta E^{*}$, corresponding to the values 93.60, 6.24 and 7.43, respectively.

Based on the response surface graphs and the desirability function (Figure 3), the optimized operating conditions can be set for the development of pirarucu fillet sous vide in the evaluated experimental area, and the optimum time-temperature conditions used at the laboratory scale are $60^{\circ} \mathrm{C}$ and $568.8 \mathrm{~s}$, with a desirability value of 0.80 . This temperature is similar to that reported by Kato et al. (2016) and Cosansu et al. (2013). According to the current investigation, the use of temperatures between 65 and $95{ }^{\circ} \mathrm{C}$ for 600 to $3600 \mathrm{~s}$, with rapid cooling to reduce the temperature of the centre of the product to $0^{\circ} \mathrm{C}$, is appropriate condition for sous vide processing of fish.

\section{Control of the best binomial time-temperature condition for sous vide processing}

Thermal profile. The control of the sous vide process registers the temperatures and times of each step of heating, processing, cooling and reheating of the sous vide pirarucu (Figure 4). In the first stage, the red line specifies the initial and final temperatures in the centre of the fillet of 25 and $60^{\circ} \mathrm{C}$, respectively, which were reached at 0 and $270 \mathrm{~s}$. This step weakly contributed to 


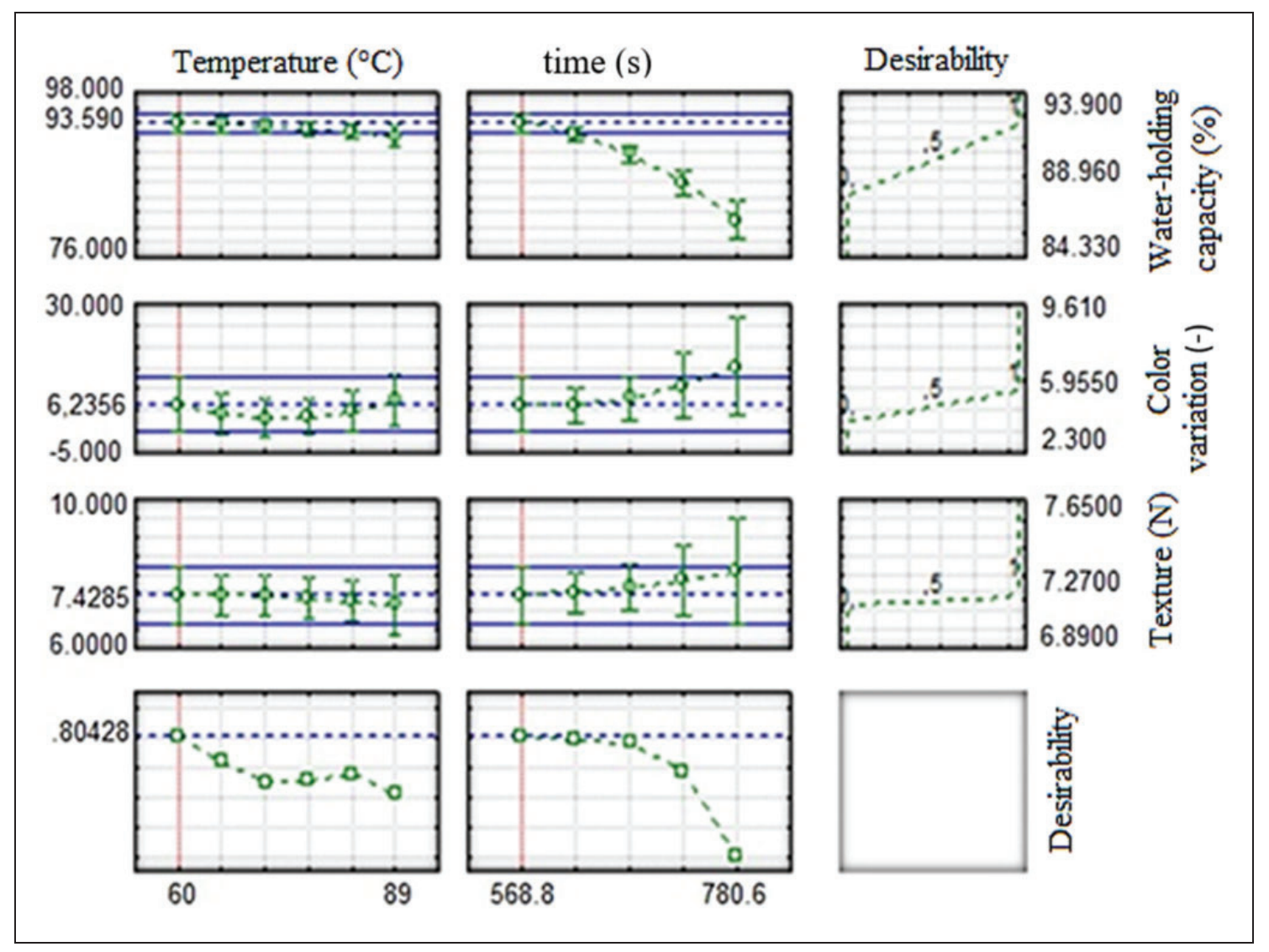

Figure 3. Profile of the predicted/optimized values and desirability function of the variables applied to the sous vide process.

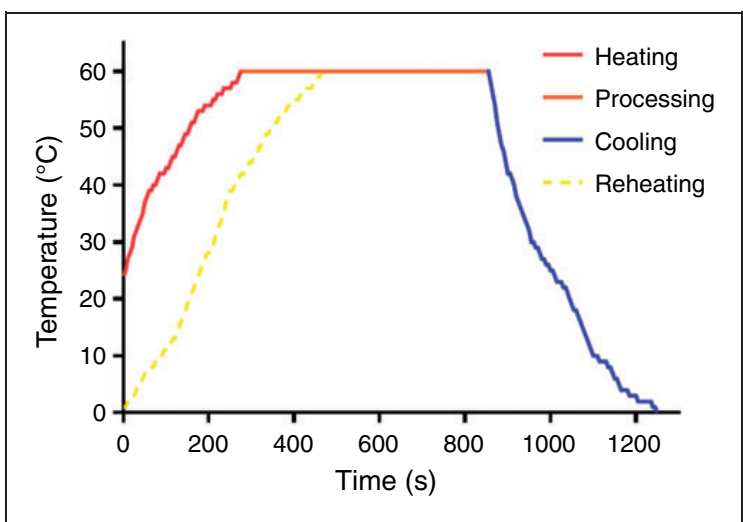

Figure 4. Thermal profiles of the best sous vide process.

the total reduction of microorganisms, including Salmonella spp., coliforms at $45^{\circ} \mathrm{C}$ and coagulase-positive Staphylococcus.

The highest influence on the lethality to the pathogenic microorganism of reference (Salmonella spp.) occurred in the second stage (orange line), when the centre of the product reached $60^{\circ} \mathrm{C}$ and remained at this temperature for $568.8 \mathrm{~s}$. According to Baldwin
(2012), the condition of $60^{\circ} \mathrm{C}$ and $328.8 \mathrm{~s}$ is sufficient to reduce Salmonella spp., to ensure microbiological safety and quality. When conditions lead to the absence of Salmonella spp. in a vacuum-packed product, a reduction of coliforms at $45^{\circ} \mathrm{C}$ and coagulase-positive Staphylococcus is implied. The third stage (blue line) registered a rapid loss of heat from 60 to $50^{\circ} \mathrm{C}$ for $60 \mathrm{~s}$. The temperature of $0^{\circ} \mathrm{C}$ was reached in about $390 \mathrm{~s}$ in an ice bath with manual stirring. Immediately after cooling, the product was stored under refrigeration $\left(1^{\circ} \mathrm{C}\right)$.

Finally, after storage, the sous vide fillet needs reheating (yellow discontinued line) before consumption. The appropriate time-temperature condition for this stage was established as $480 \mathrm{~s}$ following immersion of the fillet in the water bath at $60^{\circ} \mathrm{C}$.

Overall, the product does not represent a microbiological potential risk for consumers. Regarding the pasteurization and cooking values calculated from experimental time-temperature profiles, 613.32 and 46.53, respectively, achieved a sufficient inactivation of pathogens from pirarucu fillet for the best binomial time-temperature condition, ensuring the microbiological safety and quality attribute. 
Table 5. Microbiological analyses before and immediately after processing the sous vide product

\begin{tabular}{lll}
\hline & Values & \\
\cline { 2 - 3 } Microorganism & $\begin{array}{l}\text { Before processing the } \\
\text { sous vide product }\end{array}$ & $\begin{array}{l}\text { After processing the } \\
\text { sous vide product }\end{array}$ \\
\hline Salmonella spp. & Absence in $25 \mathrm{~g}$ & Absence in $25 \mathrm{~g}$ \\
Coagulase positive Staphylococcus & $2.00 \mathrm{a} \log \mathrm{CFU} / \mathrm{g}$ & $0.41 \mathrm{~b} \log \mathrm{CFU} / \mathrm{g}$ \\
Coliforms at $35^{\circ} \mathrm{C}$ & $2.36 \log \mathrm{MPN} / \mathrm{g}$ & - \\
Coliforms at $45^{\circ} \mathrm{C}$ & $2.63 \mathrm{a} \log \mathrm{MPN} / \mathrm{g}$ & $0.32 \mathrm{~b} \log \mathrm{MPN} / \mathrm{g}$ \\
Sulphite-reducing Clostridium & Absence & Absence \\
Mesophilic bacteria & $3.40 \mathrm{a} \log \mathrm{CFU} / \mathrm{g}$ & $1.70 \mathrm{~b} \log \mathrm{CFU} / \mathrm{g}$ \\
Psycrotrophic bacteria & $2.40 \log \mathrm{CFU} / \mathrm{g}$ & - \\
\hline
\end{tabular}

MPN: most probable number; CFU: colony forming units; "-": not performed.

Different letters in the same line indicate statistical significant difference $(p<0.05)$.

Microbiological control. The microbiological analyses before and after the sous vide processing (Table 5) verified the absence of Salmonella spp. and sulphite-reducing Clostridium, and low counts of coagulase-positive Staphylococcus $(2.00 \log \mathrm{CFU} / \mathrm{g})$ and coliforms at $45^{\circ} \mathrm{C}$ $(2.63 \log \mathrm{MPN} / \mathrm{g})$. These values were within the standards set by Brazilian legislation IN 12/2001 (Brasil, 2001a) and ICMSF (2011).

The mesophilic and psychrotrophic microorganism counts in the samples before sous vide processing were 3.40 and $2.40 \log \mathrm{CFU} / \mathrm{g}$, respectively, which decreased (1.70 log $\mathrm{CFU} / \mathrm{g})$ after sous vide processing performed under optimized conditions. The coliform results at $35^{\circ} \mathrm{C}$ also decreased from an initial value of $2.36 \mathrm{log}$ $\mathrm{CFU} / \mathrm{g}$ in the raw material to $0.32 \log \mathrm{CFU} / \mathrm{g}$ after sous vide processing. The microbiological analyses confirm that before and after the sous vide processing, hygienic and sanitary procedures were properly followed. In conclusion, the microbial load did not reach the maximum limits of $6 \log \mathrm{CFU} / \mathrm{g}$ and $7 \log$ MPN/g established by Brazilian legislation (Brasil, 2001a) and the ICMSF (2011), respectively.

\section{CONCLUSION}

The analysis of pretreatments, such as those assessed in this study for sous vide cooking, is essential to evaluate the physical characteristics of the cooked products and ensure food safety. Brining combined with the grilling pretreatment (at $200{ }^{\circ} \mathrm{C}$ for $120 \mathrm{~s}$ ) of pirarucu fillet had a synergistic effect by solving technological difficulties in the conventional process such as the appearance of white precipitates caused by denaturing proteins. The computational modelling processes corresponded with the experimental conditions of the heat pretreatment. This 3D model also showed how the heat transfer in the fillet evolved. Texture and colour variation were significantly affected by the choice of the best binomial time-temperature of the sous vide process. Cooking at $60^{\circ} \mathrm{C}$ for $568.8 \mathrm{~s}$ was the 'best' processing condition identified for developing the sous vide product according to the response surface methodology and the desirability. Based on this result, it was possible to explain changes in colour, WHC and texture, and to guarantee the food safety of the cooked products. Therefore, the development of pirarucu sous vide is an excellent option for developing a fish value-added product to be supplied to market niches.

\section{DECLARATION OF CONFLICTING INTERESTS}

The author(s) declared no potential conflicts of interest with respect to the research, authorship, and/or publication of this article.

\section{FUNDING}

The author(s) disclosed receipt of the following financial support for the research, authorship, and/ or publication of this article: The work behind this paper was funded by the Coordenação de Aperfeiçoamento de Pessoal de Nivel Superior - CAPES, Brazil. Enrique Pino-Hernández thanks to the Organization of American States (OAS - United States) and the Coimbra Group of Brazilian Universities (GCUB) under the scope of Partnerships Program for Education and Training (PAEC) to Latin America and the Caribbean, by the scholarship received for studying a Master program in the Federal University of Pará (call Brazil, OASGCUB 2013).

\section{ORCID ID}

Enrique Pino-Hernández (D) https://orcid.org/0000-00015689-198X

\section{REFERENCES}

Baldwin D. (2012). Sous vide cooking: A review. International Journal of Gastronomy and Food Science 1: 15-30. 
Brasil. Ministério da Saúde. (2001a). Aprova o Regulamento Técnico com Resolução RDC n 12, de janeiro de 2001. Padrões microbiológicos para alimentos. Diário da República Federativa do Brasil.

Brasil. Ministério da Agricultura, Pecuária e Abastecimento. (2001b). Regulamento da Inspeção Industrial e Sanitária de Produtos de Origem Animal - RIISPOA. Pescado e derivados. Capítulo VII. Seção I. Brasília. Ministério da Agricultura, Pecuária e Abastecimento.

Cortegano C, Godoy L, Petenuci M, Visentainer J, Affonso E and Gonçalves L. (2017). Nutritional and lipid profiles of the dorsal and ventral muscles of wild pirarucu. Pesquisa Agropecuária Brasil 52: 271-276.

Cosansu S, Mol S, Ucok Alakavuk D and Ozturan S. (2013). The effect of lemon juice on shelf life of sous vide packaged whiting (Merlangius merlangus euxinus, Nordmann, 1840). Food and Bioprocess Technology 6: 283-289.

Dima J, Barón P and Zaritzky N. (2012). Mathematical modeling of the heat transfer process and protein denaturation during the thermal treatment of patagonian marine crabs. Journal of Food Engineering 113: 623-634.

Downes F and Ito K. (2015). Compendium of methods for the microbiological examination of foods. American Public Health Association. 1-659. 5th edition. APHA Press.

Espinosa M, Díaz P, Linares M, Teruel M and Garrido M. (2015). Quality characteristics of sous vide ready to eat seabream processed by high pressure. LWT - Food Science and Technology 64: 657-662.

Geankoplis C. (1998). Procesos de transporte y operaciones unitarias. Cecsa. 3rd ed. Mexico: University of Minnesota.

Hernández E, Carvalho R, Joele M, Araújo C and Lourenço L. (2017). Effects of modified atmosphere packing over the shelf life of sous vide from captive pirarucu (Arapaima gigas). Innovative Food Science \& Emerging Technologies 39: 94-100.

ICMSF - International Commission on Microbiological Specifications for Foods. (2011). Microorganisms in Foods 8: Use of Data for Assessing Process Control and Product Acceptance. New York: Springer.

Kato H, Lourenço L, Araújo E, Sousa C, Joele M and Ribeiro S. (2016). Change in physical and chemical characteristics related to the binomial time-temperature used in sous pasteurization see tambaqui (Colossoma macropomum). Arquivo Brasileiro de Medicina Veterinária e Zootecnia 68: 224-232.

Kilibarda N, Brdar I, Baltic B, Markovic V, Mahmutovic H, Karabasil N, et al. (2018). The safety and quality of sous vide food. Meat Technology 59: 38-45.
Kong F, Tang J, Rasco B and Crapo C. (2007). Kinetics of salmon quality changes during thermal processing. Journal of Food Engineering 83: 510-520.

Konno K. (2017). Myosin denaturation study for the quality evaluation of fish muscle-based products. Food Science and Technology Research 23: 9-21.

Llave Y, Shibata-Ishiwatari N, Watanabe M, Fukuoka M, Hamada Sato N and Sakai N. (2018). Analysis of the effects of thermal protein denaturation on the quality attributes of sous-vide cooked tuna. Journal of Food Processing and Preservation 42: e13347.

Llave Y, Yu X, Wakisaka G, Fukuoka M and Sakai N. (2014). Visualization of browning color formation on grilled fish through a 2D simulation. Food Science and Technology Research 20: 537-545.

MATLAB and Statistics Toolbox Release R2019a, The MathWorks, Inc., Natick, Massachusetts, United States.

Matsuda H, Llave Y, Fukuoka M and Sakai N. (2013). Color changes in fish during grilling - Influences of heat transfer and heating medium on browning color. Journal of Food Engineering 116: 130-137.

Nakamura M, Mao W, Fukuoka M and Noboru S. (2011). Analysis of the color change in fish during the grilling process. Food Science Technology Research 17: 471-478.

Orrego C. (2003). Procesamiento de alimentos, Centro de Publicaciones. 1st ed. Manizales, Colombia: Universidad Nacional de Colombia.

Özyurt G, Kuley E, Özkütük S and Özogul F. (2009). Sensory, microbiological and chemical assessment of the freshness of red mullet (Mullus barbatus) and goldband goatfish (Upeneus moluccensis) during storage in ice. Food Chemistry 114: 505-510.

Pino-Hernández E, de Carvalho Júnior R, Alves R, Joele M, Silva N, da Silva E, et al. (2020). Evaluation of muscle cuts of pirarucu (Arapaima gigas) and sous vide product characterization and quality parameters. International Journal of Gastronomy and Food Science 20: 100200.

Rinaldi M, Dall'Asta C, Paciulli M, Cirlini M, Manzi C and Chiavaro E. (2014). A novel time/temperature approach to sous vide cooking of beef muscle. Food and Bioprocess Technology 7: 2969-2977.

Vieira E, Mársico E, Conte-Junior C, Damiani C, Canto A, Monteiro M, et al. (2018). Effects of different frying techniques on the color, fatty acid profile, and lipid oxidation of Arapaima gigas. Journal of Food Processing and Preservation 42: 1-8.

Yu X, Llave Y, Fukuoka M and Sakai N. (2014). Estimation of color changes in fish surface at the beginning of grilling based on the degree of protein denaturation. Journal of Food Engineering 129: 12-20. 